\title{
PENERAPAN SISTEM MANAJEMEN STRATEGI BERBASIS BALANCE SCORECARD PADA ORGANISASI SEKTOR PUBLIK
}

\author{
Nawirah \\ Jurusan Akuntansi Fakultas Ekonomi \\ Universitas Islam Negeri Maulana Malik Ibrahim Malang \\ J1. Gajayana No. 50, Tlp 0341-558881, Fax. 0341-558881 \\ E-Mail dnawirah@yahoo.com
}

\begin{abstract}
Management strategies has become an important issue for the public sector. Management strategies can be understood as the process of selection and implementation strategies. In this paper tries to provide an alternative thinking in the management of performance improvement strategies for the public sector through the balanced scorecard.

Balanced Scorecard is not only used by private sector organizations but also public sector organizations. Public sector organizations are organizations that provide services to people with not-for-profit purposes. To be used by public sector organizations, the balanced scorecard should be modified. This paper also discusses how to build a balanced scorecard, include determining strategic objectives, targets to be achieved as well as initiatives, and implementing balanced scorecard in public sector organizations. The concept is applied in a balanced scorecard, which the visio, mission, strategy translates the strategic management approach through a financial perspective, customer, internal business processes, learning and growth.
\end{abstract}

Keywords: balanced scorecard, strategy management, public sector organizations

\begin{abstract}
Abstrak
Manajemen strategi telah menjadi isu penting bagi sektor publik. Manajemen strategi dapat dipahami sebagai proses pemilihan dan penerapan strategi-strategi. Didalam paper ini mencoba menyajikan alternatif pemikiran didalam peningkatan performansi manajemen strategi untuk sektor publik melalui balanced scorecard.

Balanced scorecard tidak saja digunakan oleh organisasi sector swasta tetapi juga organisasi sector publik. Organisasi sektor publik adalah organisasi yang menyediakan jasa pada masyarakat dengan tujuan bukan untuk mencari profit. Untuk dapat digunakan oleh organisasi sektor publik, balanced scorecard tersebut harus dimodifikasi. Paper ini juga membahas bagaimana membangun balanced scorecard, meliputi menentukan tujuan strategis, target yang ingin dicapai serta inisiatif, dan mengimplementasikan balanced scorecard pada organisasi sector publik. Konsep yang diterapkan dalam balanced scorecard, dimana visi, misi, strategi diterjemahkan dengan pendekatan manajemen
\end{abstract}


strategik melalui perspektif keuangan, pelanggan, proses bisnis internal, pertumbuhan dan pembelajaran.

Kata kunci: balanced scorecard, manajemen strategi, organisasi sektor publik

\section{Pendahuluan}

Pernyataan visi dan misi suatu organisasi merupakan gambaran ideal organisasi atas apa yang dicapai dimasa yang akan datang melalui kegiatan operasionalnya. Untuk mencapai visi dan misi tersebut organisasi menyusun rencana-rencana strategis yang harus dilakukan oleh setiap anggota organisasi. Dalam mengimplementasikan rencanarencana strategis tersebut, organisasi sering menghadapi hambatan bahkan kegagalan. Hambatan-hambatan yang menyebabkan organisasi mengalami kegagalan dalam mengimplementasi rencana-rencana strategis tersebut antara lain:

1. Hambatan visi, dimana tidak banyak orang dalam organisasi memahami strategi organisasi

2. Hambatan orang, banyak orang dalam organisasi memiliki tujuan yang tidak terkait dengan strategi organisasi

3. Hambatan sumber daya, waktu, energi, dan uang tidak dialokasikan pada hal-hal yang penting dalam organisasi

4. Hambatan manajemen, manajemen menghabiskan terlalu sedikit waktu untuk strategi organisasi dan terlalu banyak waktu untuk pembuatan keputusan taktis jangka pendek (Gaspersz, 2006:2).

Organisasi membutuhkan alat komunikasi yang dapat digunakan untuk mengkomunikasikan rencana-rencana strategis tersebut kepada semua anggota organisasi. Alat komunikasi yang bisa digunakan oleh organisasi adalah Balanced Scorecard (Malina dan Selto 2001).

Organisasi sektor publik adalah organisasi yang mengelola misi dan tanggung jawab yang dibebankan oleh publik baik finansial maupun non financial (Mardiasmo, 2009:2). Rangkaian yang saling berkaitan menuntut adanya infrastruktur sistem pertanggungjawaban kinerja yang memadai. Pertanggungjawaban yang disusun oleh organisasi sektor publik harus nampak dari sisi keuangan maupun non keuangan dan 
keduanya seharusnya harus terukur dan dapat diperhitungkan dan dianalisis secara akurat, dengan demikian akan terwujud asas-asas pemerintahan yang baik dengan terwujudnya entitas organisasi sektor publik yang menyiapkan pertanggungjawaban kinerjanya serta dapat diaudit (Bastian, 2007:42).

Meskipun organisasi publik tidak bertujuan untuk mencari profit, organisasi ini terdiri dari unit-unit yang saling terkait yang mempunyai misi yang sama yaitu melayani masyarakat. Untuk itu organisasi publik harus dapat menterjemahkan misinya kedalam strategi, tujuan, ukuran serta target yang ingin dicapai, yang kemudian dikomunikasikan kepada unit-unit yang ada untuk dapat dilaksanakan sehingga semua unit mempunyai tujuan yang sama yaitu pencapaian misi organisasi. Untuk itu organisasi publik dapat menggunakan balanced scorecard dalam menterjemahkan misi organisasi kedalam serangkaian tindakan untuk melayani masayarakat. Dengan adanya perbedaan-perbedaan antara organisasi swasta dan publik, maka balanced scorecard harus dimodifikasikan terlebih dahulu agar sesuai dengan kebutuhan organisasi public (Rohm, 2004).

\section{Sistem Manajemen Strategis}

Sistem manajemen strategis merupakan proses merumuskan dan mengimplementasikan strategi untuk mewujudkan visi secara terus menerus secara terstruktur. Strategi adalah pola tindakan terpilih untuk mencapai tujuan tertentu. Pada mulanya, sistem manajemen strategis bercirikan:

1. Mengandalkan anggaran tahunan

2. Berjangka panjang

3. Berfokus pada kinerja keuangan

Sistem manajemen strategis diperlukan karena organisasi dituntut untuk berkembang secara terencana dan terukur, sehingga memerlukan peta perjalanan dalam menghadapi masa depan yang tidak pasti, memerlukan langkah-langkah strategis dan perlu mengarahkan kemampuan dan komitmen sumber daya manusia untuk mewujudkan tujuan organisasi. Balanced scorecard memberikan solusi terhadap tuntutan ini.

\section{Balance Scorecard}

Kemunculan gagasan balanced scorecard berawal dari temuan riset Kaplan dan Norton (dari Harvard Business School) pada awal tahun 1990-an. Konsep awal balanced 
scorecard berdasarkan riset tersebut ditulis pada tahun 1992 di majalah prestisius Harvard Business Review. Pada tahun 1996 Norton dan Kaplan menerbitkan buku The Balanced Scorecard Translating Strategy into Action. Buku ini semakin mempopulerkan balanced scorecard, sampai ke negara-negara di Eropa, Australia dan Asia. Belum lama ini juga menerbitkan buku The Strategy Focused Organisation How BSC Companies Thrive in the New Business Environment (2001). Para penemu dan rekan-rekannya membangun sebuah lembaga Balanced Scorecard Collaboration untuk mempopulerkan penggunaan balanced scorecard pada berbagai institusi di berbagai negara.

Balanced scorecard secara singkat adalah suatu sistem manajemen untuk mengelola implementasi strategi, mengukur kinerja secara utuh, mengkomunikasikan visi, strategi dan sasaran kepada stakeholders. Kata balanced dalam balanced scorecard merujuk pada konsep keseimbangan antara berbagai perspektif, jangka waktu (pendek dan panjang), lingkup perhatian (intern dan ekstern). Kata scorecard mengacu pada rencana kinerja organisasi dan bagian-bagiannya serta ukurannya secara kuantitatif (Kaplan dan Norton, 2001:7).

Menurut Mulyadi (2001:1) mendefinisikan Balanced Scorecard berdasarkan asal katanya yaitu balanced (seimbang) dan scorecard (kartu skor). Pengertian Balanced Scorecard menurut asal katanya adalah kartu yang digunakan untuk mencatat skor hasil kinerja seseorang. Kartu skor juga dapat digunakan untuk merencanakan skor yang hendak diwujudkan oleh personel masa depan. Melalui kartu skor, skor yang hendak diwujudkan personel di masa depan dibandingkan dengan hasil kinerja sesungguhnya. Hasil perbandingan ini digunakan untuk melakukan evaluasi atas kinerja personel yang bersangkutan. Kata berimbang dimaksudkan untuk menunjukkan bahwa kinerja personel diukur secara berimbang dari aspek: keuangan dan non keuangan, jangka pendek dan jangka panjang, intern dan ekstern.

Balanced scorecard memberi manfaat bagi organisasi dalam beberapa cara:

1. Menjelaskan visi organisasi

2. Menyelaraskan organisasi untuk mencapai visi itu

3. Mengintegrasikan perencanaan strategis dan alokasi sumber daya 
4. Meningkatkan efektivitas manajemen dengan menyediakan informasi yang tepat untuk mengarahkan perubahan.

Beberapa alasan yang membedakan balanced scorecard dengan konsep lainnya, adalah :

1. Balanced scorecard adalah alat komprehensif untuk memahami pelanggan dan kebutuhannya dan kesenjangan kinerja

2. Balanced scorecard menyiapkan logika untuk menciptakan modal intangible dan intelektual.

3. Balanced scorecard mampu mengartikulasi strategi pertumbuhan menjadi keandalan bisnis yang fokus kepada upaya-upaya non finansial.

4. Balanced scorecard memampukan karyawan memahami strategi dan kaitan sasaran ke dalam operasi perusahaan dari hari ke hari.

5. Balanced scorecard memfasilitasi umpan balik review kerja dari waktu ke waktu. Dalam menerapkan balanced scorecard, Kaplan dan Norton (1996:129), mensyaratkan dipegangnya Lima prinsip utama berikut:

1. Menerjemahkan sistem manajemen strategi berbasis balanced scorecard ke dalam terminologi operasional sehingga semua orang dapat memahami

2. Menghubungkan dan menyelaraskan organisasi dengan strategi itu. Ini untuk memberikan arah dari eksekutif kepada staf garis depan

3. Membuat strategi merupakan pekerjaan bagi semua orang melalui kontribusi setiap orang dalam implementasi strategis

4. Membuat strategi suatu proses terus menerus melalui pembelajaran dan adaptasi organisasi

5. Melaksanakan agenda perubahan oleh eksekutif guna memobilisasi perubahan.

\section{Sistem Manajemen Strategi berbasis Balance Scorecard}

Sistem manajemen strategi berbasis balance scorecard adalah manajemen strategi yang dilaksanakan secara bersistem yang menggunakan balanced scorecard dalam sistem perencanaan strategi sebagai alat penerjemah visi, misi, tujuan, keyakinan dasar, nilai dasar, dan strategi organisasi. 
Mulyadi (2001:18) menyatakan bahwa peran balanced scorecard dalam sistem manajemen strategis adalah:

1. Memperluas perspektif dalam setiap tahap sistem manajemen strategis

2. Membuat fokus manajemen menjadi seimbang

3. Mengaitkan berbagai sasaran secara koheren

4. Mengukur kinerja secara kuantitatif.

Kelebihan sistem manajemen strategis berbasis balanced scorecard dibandingkan konsep manajemen yang lain adalah bahwa dia menunjukkan indikator outcome dan output yang jelas, indikator internal dan eksternal, indikator keuangan dan non-keuangan, dan indikator sebab dan akibat. Balanced scorecard juga diterapkan dalam situasi-situasi yang rutin, antara lain: pada saat menyusun rencana alokasi anggaran, menyusun manajemen kinerja, melakukan sosialisasi terhadap kebijakan baru, memperoleh umpan balik, meningkatkan kapasitas staf.

Ada kemungkinan kegagalan dalam menerapkan balanced scorecard. Menyusun balanced scorecard bukanlah pekerjaan yang mudah. Banyak organisasi gagal membuat balanced scorecard karena berbagai sebab. Sebab-sebab itu antara lain adalah:

1. Tidak ada komitmen pimpinan

2. Terlalu sedikit staf terlibat

3. Scorecard disimpan saja

4. Proses penyusunan yang lama dan sekali jadi

5. Menganggap balanced scorecard sebagai sebuah proyek

6. Kesalahan memilih konsultan

7. Menggunakan balanced scorecard hanya untuk keperluan pemberian kompensasi Manajemen strategi berbasis balanced scorecard terdiri dari enam tahap: (Mulyadi, 2001:46)

1. Perumusan Strategi (Strategy Formulation)

Proses manajemen strategik diawali dengan perumusan strategi. Strategi dirumuskan melalui sistem perumusan strategi yang terdiri dan empat tahap utama:

a. Trendwatching, pengamatan lingkungan yang akan dimasuki oleh perusahaan di masa depan 
b. Analisis SWOT (strengths, weaknesses, opportunities, dan threats),

c. Envisioning, penentuan misi, visi, tujuan (goals) keyakinan dasar, dan nilai dasar

d. Pemilihan strategi, penentuan strategi yang digunakan untuk mewujudkan visi organisasi.

2. Perencanaan Strategi (Strategic Planning)

Organisasi merumuskan strategi pilihan untuk mewujudkan visi melalui misi organisasi, strategi tersebut kemudian perlu diimplementasikan. Langkah pertama pengimplementasian strategi pilihan adalah dengan melaksanakan perencanaan strategik melalui sistem perencanaan strategik. Dalam langkah ini, misi, visi, tujuan, keyakinan dasar, nilai dasar, dan strategi diterjemahkan ke dalam sasaran dan inisiatif strategik.

Sasaran strategik merupakan sasaran-sasaran masa depan yang hendak dituju oleh organisasi sebagai penerjemahan strategi untuk mewujudkan visi dan tujuan (goals). Oleh karena perwujudan sasaran strategik memerlukan waktu lama di masa depan, organisasi perlu menetapkan tonggak-tonggak (milestones) untuk menandai pencapaian di sepanjang perjalanan untuk mewujudkan sasaran strategik. Untuk mewujudkan sasaran strategik diperlukan inisiatif strategik berupa prakarsa besar yang akan dilaksanakan oleh organisasi. Inisiatif strategik inilah yang kemudian dijabarkan ke dalam program dalam proses penyusunan program (programming) dan pada gilirannya program yang dihasilkan dan penyusunan program inilah yang kemudian dijabarkan ke dalam anggaran dalam proses penyusunan anggaran (budgeting).

\section{Penyusunan Program(Programming System)}

Penyusunan program adalah proses penjabaran inisiatif strategik ke dalam program. Pelaksanaan inisiatif strategik memerlukan perencanaan sistematik langkah-langkah besar yang akan ditempuh oleh organisasi dalam jangka panjang ke depan beserta perkiraan sumber daya yang diperlukan untuk dan diperoleh dan usaha menjalankan langkah-langkah tersebut. Penyusunan program dilaksanakan 
melalui sistem penyusunan program yang menghasilkan keluaran berupa program beserta prakiraan sumber daya yang diperlukan.

4. Penyusunan Anggaran(Budgeting)

Penyusunan anggaran adalah proses penyusunan rencana laba jangka pendek (biasanya untuk jangka waktu satu tahun atau kurang) yang berisi langkah-langkah yang akan ditempuh oleh organisasi dalam melaksanakan sebagian dan program. Penyusunan anggaran dilaksanakan melalui sistem penyusunan anggaran.

Penyusunan anggaran bertujuan untuk menentukan kegiatan tahun berikutnya dan sumber daya yang diperlukan. Anggaran disusun berdasarkan iniatif yang telah dirumuskan. Anggaran yang baik adalah: merupakan rencana tindakan terperinci, merupakan rencana satu-dua tahunan, menguraikan biaya yang diperlukan, mengidentifikasi pencapaian terpenting kegiatan tsb., menyebutkan siapa yang akan bertanggung jawab, sebagai referensi menyusun rencana kinerja individual, ditulis secara singkat namun lengkap, alat untuk memantau kinerja dan diperbarui apabila terjadi perubahan-perubahan. Dengan demikian balanced scorecard mendukung suatu sistem manajemen yang lengkap dengan mengkaitkan strategi jangka panjang ke penganggaran tahunan.

5. Pengimplementasian

Tahap ini melaksanakan kegiatan sesuai rencana.

\section{Pemantauan}

Tahap ini membandingkan kinerja dengan target. Berbagai kemungkinan hasil adalah berhasil, gagal, dan variasi diantara keduanya. Prinsip umum dalam pemantauan adalah mengukur kinerja, membandingkan kinerja, melakukan tinjauan ulang, memberi penghargaan dan mengidentifikasi hasil yang dicapai, mempelajari pengalaman, menyesuaikan dan menyegarkan strategi, dan melakukan perbaikan. Pemantauan harus diikuti dengan pengendalian. Jenis-jenis pengendalian: pengendalian premis/asumsi dasar, pengendalian implementasi, pengawasan strategis, dan pengendalian berdasarkan sinyal-sinyal khusus. 
Pengendalian dapat lebih mudah dilakukan dengan menggunakan balanced scorecard karena tolok ukurnya sudah diperjelas.

Konsep balanced scorecard berkembang sejalan dengan perkembangan pengimplementasian konsep tersebut. Pada tahap awal eksperimennya, balanced scorecard merupakan kartu skor yang digunakan untuk mencatat hasil skor kinerja eksekutif. Melalui kartu skor, skor yang hendak diwujudkan eksekutif dimasa mendatang dibandingkan dengan hasil kinerja sesungguhnya. Hasil perbandingan ini digunakan untuk evaluasi atas kinerja eksekutif.

Dalam perkembangan selanjutnya, balanced scorecard tidak hanya berkaitan dengan kartu yang dipakai untuk mengukur kinerja eksekutif. Balanced scorecard lebih dimanfaatkan sebagai alat eksekutif untuk perencanaan strategic, yaitu sebagai alat untuk menerjemahkan visi, misi, tujuan, keyakinan dasar, nilai dasar dan strategi organisasi ke dalam rencana tindakan (actions plan) yang komprehensif, koheren, terukur dan berimbang. Kekuatan sesungguhnya balanced scorecard terletak bukan hanya pada kemampuannya sebagai pengukur kinerja eksekutif, namun justru terletak pada kemampuannya sebagai alat perencanaan strategik.

\section{Pengembangan Organisasi Sektor Publik dengan Balance scorecard}

Pengembangan organisasi merupakan upaya meningkatkan kemampuan organisasi berdasarkan persepektif waktu jangka panjang yang terdiri dari serangkaian penahapan dengan penekanan pada hubungan antar individu, kelompok dan organisasi sebagai keseluruhan. Pengembangan organisasi dapat juga dikatakan aplikasi pendekatan kesisteman terhadap hubungan fungsional, struktural, teknikal, dan personal dalam organisasi.

Pengembangan organisasi merupakan suatu perubahan organisasi, oleh karena itu Siagian (1995:21) mengatakan bahwa persepsi tentang perlunya perubahan harus dirasakan karena hanya dalam kondisi demikianlah para anggota organisasi dapat diyakinkan bahwa dalam upaya mencapai tujuan dan berbagai sasaran organisasi, diperlukan cara kerja baru, metode kerja baru, dan bahkan mungkin strategi dan visi yang baru. Salah satu ciri umum pengembangan organisasi adalah bahwa pengembangan 
organisasi merupakan suatu proses yang terus menerus dan dinamis. Pelaksana harus mampu mengubah strategi selama proses sedang berlangsung sebagai akibat masalahmasalah yang timbul dan kejadian-kejadian organisasi.

Tujuan finansial bukan merupakan tujuan utama yang memadai untuk sektor publik. Organisasi sector publik mengukur keberhasilan mereka melalui kemampuan mengatur pengeluaran sejumlah anggaran yang berwujud pada kebutuhan masyarakat, instansi pemerintah lain dan pemerintah pusat (stakeholders). Dengan demikian, fokus utama organisasi pemerintah bukan pada pencapaian tujuan finansial namun pada tujuan yang berfokus pada pelanggan, yang dalam hal ini adalah masyarakat dan pemerintah pusat (Gaspersz, 2006:210).

Keberhasilan pemerintah dan nirlaba (non-profit organizations) diukur melalui efektivitas dan effisiensi dalam memenuhi kebutuhan stakeholders yang diwujudkan melalui tujuan-tujuan yang berwujud (tangibles objectives). Para pejabat pemerintah dapat mulai mendefinisikan segmen masyarakat yang dilayani, dan kemudian memilih tujuan dan ukuran kinerja untuk segmen tersebut. Pernyataan visi, misi dan strategi organisasi pemerintah yang berfokus pada masyarakat harus diterjemahkan dalam tujuan yang spesifik yang berorientasi pada masyarakat dan dikomunikasikan ke seluruh organisasi.

Melalui scorecard organisasi sektor publik akan mampu menjelaskan misinya kepada masyarakat dan dapat mengidentifikasi indikator kepuasan masyarakat secara lebih transparan, objektif dan terukur serta mampu mengidentifikasi proses kerja dan kwalitas sumber daya manusia yang dibutuhkannya dalam mencapai misi dan strateginya. Sedangkan didalam proses implementasinya, kegiatan yang dilakukan oleh organisasi publik akan dapat menghadirkan suatu sistem manajemen startegik yang berorientasi pada masyarakat.

\section{Penerapan Sistem Manajemen Strategi berbasis Balance Scorecard pada Organisasi}

\section{Sektor Publik}

Semakin nyata dan jelas tentang isu-isu kontrol strategi pada sektor publik hal ini menjadikan pendekatan balance scorecard akan efektif untuk isu-isu kontrol strategi tersebut. 
Institusi public perlu mengadopsi balanced scorecard. Pemerintah pada era sekarang ini, baik pemerintah pusat, daerah maupun lokal diharapkan untuk menjadi: akuntabel, kompetitif, ramah rakyat, dan berfokus pada kinerja. Organisasi sektor publik juga ditantang untuk memenuhi harapan berbagai kelompok stakeholders (yaitu penerima layanan, karyawan, lembaga pemberi pinjaman/hibah, masyarakat, dan pembayar pajak). Tuntutan ini mengharuskan organisasi sektor publik untuk bertindak profesional sebagaimana yang dilakukan oleh organisasi sektor swasta. Organisasi sektor publik harus mempunyai sistem manajemen strategis. Karena dunia eksternal adalah sangat tidak stabil, maka sistem perencanaan harus mengendalikan ketidakpastian yang ditemui. Organisasi sektor publik, dengan demikian harus berfokus strategi. Strategi ini lebih bersifat hipotesis, suatu proses yang dinamis, dan merupakan pekerjaan setiap staf. Organisasi sektor publik harus juga merasakan, mengadakan percobaan, belajar, dan menyesuaikan dengan perkembangan. Agar organisasi sektor publik dapat berfokus pada strategi yang sudah dirumuskan, maka organisasi pemerintah juga harus menterjemahkan strategi ke dalam terminologi operasional, menyelaraskan organisasi dengan strategi (dan bukan sebaliknya), memotivasi staf sehingga membuat strategi merupakan tugas setiap orang, menggerakkan perubahan melalui kepemimpinan eksekutif, dan membuat strategi sebagai suatu proses yang berkesinambungan.

Balanced scorecard sebaiknya dikembangkan oleh setiap organisasi sector public untuk mempertajam perannya dalam menjalankan fungsi-fungsi pemerintahan, sehingga membedakannya dengan organisasi sektor publik lain. Tugas pengawasan oleh DPR terhadap pemerintah akan dipermudah jika instansi publik memiliki strategi berbasis balanced scorecard. Perumusan balanced scorecard bukan suatu pekerjaan sekali jadi, melainkan tugas yang terus menerus, dengan setiap saat ada proses penyempurnaan dan yang terpenting adalah dimanfaatkan untuk mencapai visi dan misi organisasi.

Ada empat perspektif yang terkandung di dalam balanced scorecard apabila dihubungkan dengan organisasi sector public sangat relevan dan memungkinkan untuk diadakan pengukuran. (Gaspersz, 2006:211)

1. Perspektif pelayanan, yaitu sejauh mana kepuasan masyarakat terhadap pelayanan yang diberikan oleh pemerintah. Kepuasan tersebut dapat diukur dengan jumlah 
keluhan dan komplain masyarakat terhadap pelayanan public yang diberikan oleh pemerintah melalui aspirasi yang disampaikan masyarakat di DPR/DPRD, di media masa, media elektronik dll. Keluhan tersebut dapat terjadi karena pelayanan yang diberikan belum baik, seperti:

a. Keluhan karena lamanya waktu pelayanan publik

b. Keluhan karena kualitas hasil pelayanan public belum baik

c. Bisa juga terjadi karena sikap dan perilaku aparat pelayanan public yang memang belum bagus.

2. Perspektif bisnis internal dikaitkan dengan proses internal pada organisasi public, yakni kinerja pegawai, sejauh mana organisasi public mengadakan inovasi, maksimalisasi produk kebijakan dalam pelayanan internal serta interaksi masyarakat terhadap pelayanan yang diberikan penilaian ini dikaitkan dengan sikap dan perilaku orang atau aparat yang melayani.

3. Perspektif pembelajaran dan pertumbuhan di dalam organisasi public mencakup tentang pemberdayaan sumber daya manusia sebagai perangkat dari organisasi public. Pendidikan dan pembelajaran perlu diberikan kepada karyawan agar termotivasi memiliki keahlian dan keterampilan kerja memperbaiki pola kerja, system kerja, sikap dan perilaku di dalam bekerja. Sebab kalau aparat pintar, kualitas pekerjaan baik, waktu pelayanan cepat akan diperoleh penghematan biaya.

4. Perspektif keuangan/financial, Perspektif kinerja financial merupakan hasil dari suatu proses yang berlanjut karena adanya peningkatan sumber daya yang dimiliki.

Menurut Gaspersz (2006:207), terdapat perbedaan perspektif balance scorecard yang diterapkan dalam sektor publik dengan yang diterapkan pada sektor swasta yang berorientasi pada keuntungan, seperti yang ditunjukkan pada Tabel 1

Tabel 1. Perbedaan Perspektif Balance Scorecard pada Sektor Publik dan Swasta

\begin{tabular}{|l|l|l|}
\hline \multicolumn{1}{|c|}{ Perspektif } & \multicolumn{1}{|c|}{ Sektor publik } & Sektor Swasta \\
\hline Finansial & $\begin{array}{l}\text { Bagaimana kita melihat/ } \\
\text { memandang dan }\end{array}$ & $\begin{array}{l}\text { Bagaimana kita melihat/ } \\
\text { memandang dan }\end{array}$ \\
\hline
\end{tabular}




\begin{tabular}{|c|c|c|}
\hline & $\begin{array}{l}\text { memberikan nilai pada } \\
\text { stakeholders? }\end{array}$ & $\begin{array}{l}\text { memberikan nilai kepada } \\
\text { pemegang saham? }\end{array}$ \\
\hline Pelanggan & $\begin{array}{l}\text { Bagaimana stakeholders } \\
\text { yang menggunakan } \\
\text { jasa/pelayanan publik } \\
\text { memandang dan } \\
\text { mengevaluasi kami? }\end{array}$ & $\begin{array}{l}\text { Bagaimana pelanggan } \\
\text { melihat atau memandang } \\
\text { dan mengevaluasi kinerja } \\
\text { kami? }\end{array}$ \\
\hline $\begin{array}{l}\text { Pembelajaran dan } \\
\text { Pertumbuhan }\end{array}$ & $\begin{array}{l}\text { Dapatkah kita melanjutkan } \\
\text { untuk meningkatkan dan } \\
\text { menciptakan nilai bagi } \\
\text { stakeholders? }\end{array}$ & $\begin{array}{l}\text { Dapatkah kita melanjutkan } \\
\text { untuk meningkatkan dan } \\
\text { menciptakan nilai bagi } \\
\text { pelanggan, pemegang } \\
\text { saham, karyawan, } \\
\text { manajemen? }\end{array}$ \\
\hline $\begin{array}{l}\text { Proses Bisnis } \\
\text { Internal }\end{array}$ & $\begin{array}{l}\text { Apakah program-program } \\
\text { pembangunan yang } \\
\text { dilaksanakan telah } \\
\text { memberikan hasil-hasil } \\
\text { sesuai dengan yang } \\
\text { diharapkan? }\end{array}$ & $\begin{array}{l}\text { Apakah yang harus } \\
\text { diunggulkan dari proses } \\
\text { dan produk kami? }\end{array}$ \\
\hline
\end{tabular}

Sumber: Gaspersz 2006

Dengan adanya pelaksanaan kegiatan atau produk layanan yang baik selanjutnya akan memperoleh hasil respon positif dari masyarakat dalam bentuk pembayaran pajak dan retribusi daerah atau sumber lainnya. Ini adalah hasil akhir sebagai akibat dari tiga aspek berjalan dengan baik. Oleh karena itu keuangan organisasi public yang baik berimplikasi pada kualitas pelayanan, seperti penyerahan produk hasil layanan tepat waktu, kualitas produk/jasa layanan public menjadi lebih baik, kesejahteraan pegawai meningkat dan pegawai termotivasi untuk bekerja lebih baik karena imbalan yang tersedia serta hasil pekerjaan mereka sangat dihargai.

Tujuan penerapan balance scorecard pada pengukuran kinerja organisasi public adalah untuk menyatakan adanya keseimbangan antara berbagai ukuran internal dan 
eksternal. Untuk ukuran internal atau pihak pemerintah yang mengalokasikan anggaran dan pihak eksternal atau masyarakat penerima manfaat atau pihak yang dilayani dengan menggunakan berbagai ukuran seperti: kecepatan, ketepatan dan kualitas pelayanan di bidang kesehatan, di bidang pendidikan, bidang perhubungan, bidang transportasi, bidang pelayanan administrasi umum kemasyarakatan seperti KTP dan perizinan termasuk didalam membangun fasilitas public seperti jalan dan gedung.

Balance scorecard lebih dari sekedar pengukuran taktis atau operasional tetapi pada organisasi yang inovatif menggunakan scorecard sebagai sebuah system manajemen strategis untuk mengelola strategi jangka panjang organisasi yang menggunakan focus pengukuran kinerja scorecard untuk menghasilkan berbagai proses manajemen penting sebagai berikut:

1. Memperjelas dan menerjemahkan misi dan strategi organisasi

2. Mengkomunikasikan dan mengaitkan berbagai tujuan strategis

3. Merencanakan dan menetapkan sasaran untuk menyelaraskan berbagai inisiatif organisasi

4. Meningkatkan umpan balik dan pembelajaran utamanya didalam membenahi strategis organisasi menuju pelayanan yang lebih baik.

\section{Tantangan untuk Sistem Manajemen Strategik pada Organisasi Sektor Publik}

Kesadaran untuk berhubungan dengan strategi pada organisasi sektor publik adalah merupakan hal yang baru. Perencaaan sudah merupakan hal umum dilakukan oleh organisasi sektor publik, tetapi perencaaan bukanlah strategi. Strategi merupakan positioning organisasi di masa depan dengan memberikan daya ungkit melalui aset-aset yang dimiliki untuk menciptakan asset yang dapat membawa organisasi pada posisi superior terhadap pesaing melalui penciptaan nilai. Manajemen strategi pada organisasi sektor publik bukanlah merupakan adaptasi sederhana dari teori strategi sektor bisnis.

Sudah menjadi pemikiran umum bahwa organisasi sektor publik diposisikan sebagai organisasi yang berada dalam lingkungan yang fakum dari kompetisi. Sevaliditas apapun pandangan tersebut di masa lalu, saat ini pandangan tersebut tidak menyakinkan sama sekali. Secara gambaran, semua organisasi akan beroperasi dalam lingkungan kompetisi, baik kompetisi tersebut dalam konteks menentukan pilihan supplier yang 
berkualitas ataukah dalam konteks pelayanan kepada publik. Terlebih bahwa globalasi yang mengiringi era informasi telah membawa perubahan keseluruh sektor lini kehidupan manusia, dimana asumsi-asumsi pada era industri tidak berlaku lagi. Begitu pula organisasi sektor publik tidak akan lengang atau fakum lagi dari aspek persaingan, hal ini memaksa struktur organisasi harus memasukkan unsur kompetisi dan inovasi (Wilopo, 2003).

\section{Kesimpulan}

Manajemen strategi sektor publik mengarahkan organisasi sektor publik untuk melakukan perencanaan manajemen dengan mempertimbangkan dengan baik faktorfaktor pendukung dan penghambat dalam organisasi melalui salah satu alat manajemen stratejik yaitu analisis SWOT. Analisis SWOT berusaha untuk menganalisis faktor pendukung dan penghambat yang ada dalam organisasi kemudian berusaha menterjemahkannya ke dalam suatu strategi utama untuk mencapai visi, misi dan tujuan organisasi.

Balanced Scorecard adalah sebuah cara pandang baru bagaimana suatu organisasi akan dapat lebih baik lagi dikelola. Balanced scorecard merupakan bagian dari sistem manajemen strategis, yang perlu dirumuskan oleh setiap organisasi, agar dapat mencapai visi dan misinya secara efektif. Balanced scorecard memberikan prosedur bagaimana tujuan organisasi dirinci ke dalam sasaran-sasaran dalam berbagai perspektif secara lengkap, dengan ukuran-ukuran yang jelas. Balanced scorecard merupakan mekanisme untuk membuat organisasi, termasuk organisasi pemerintah, berfokus pada strategi, karena penerapan balanced scorecard memungkinkan semua unit dalam organisasi memberikan kontribusi secara terukur pada pelaksanan strategi organisasi.

Balanced scorecard dapat digunakan pada organisasi publik setelah dilakukan modifikasi dari konsep balanced scorecard yang awalnya ditujukan bagi organisasi bisnis. Modifikasi tersebut antara lain adalah dalam hal misi organisasi publik, sehingga tujuan utama suatu organisasi publik adalah memberi pelayanan kepada masyarakat dapat tercapai secara efektif dan efisien. Bagian lain yang perlu dimodifikasi adalah posisi antara perspektif financial dan perspektif pelanggan. Selanjutnya perspektif customers 
diubah menjadi perspektif customers and stakeholders dan perspektif learning and growth menjadi perspektif employess and organization capacity.

\section{Daftar Pustaka}

Bastian, Indra (2007). Audit Sektor Publik. Penerbit Salemba Empat. Edisi Dua, Jakarta.

Gaspersz, Vincent (2006), Sistem Manajemen Terintegrasi: Balanced Scorecard dengan Six Sigma untuk Organisasi Bisnis dan Pemerintah, Gramedia, Cetakan Kedua, Jakarta.

Hitt, Michael A, R. Duane Ireland, and Robert E.Hoskisson (2005), Strategic Management-Competitiveness and Globalization, Thomson International student edition USA.

Bawono, Icuk Rangga (2003), Manajemen Strategik Sektor Publik: Langkah Tepat Menuju Good Governance, Jurnal Fakultas Ekonomi UNSOED Purwokerto

Imelda (2004), Implementasi Balanced Scorecard pada Organisasi Publik, Jurnal Ekonomi Akuntansi-Universitas Kristen Petra, Volume 6, No.2, Hal 106-122.

Kaplan, Robert S dan Norton, David P (1996), Balanced Scorecard, Penerbit Erlangga, Jakarta.

Kaplan, Robert S dan Norton, David P (2001), Balanced Scorecard: Menerapkan Strategi menjadi Aksi, Penerbit Erlangga, Jakarta. 
Kaplan, Robert S dan Norton, David P (2001). The Strategy Focus Organization: How Balanced Scorecard Companies Thrive in the New Business Environment. Massachusetts: Harvard Business School Publishing Corporation.

Malina, Mary, A. dan Selto, Frank, H (2004), Communicating and Controlling Strategy: an Emperical Study of the Effectiveness of the Balanced Scorecard, http: Ilwww.ssrn.com.

Suhendra, Maman (2004), Evaluasi atas Penerapan Balanced Scorecard sebagai Sistem Pengukuran Kinerja Perusahaan, Jurnal Ekonomi dan Keuangan, Volume 8, No.2.

Mardiasmo (2009), Akuntansi Sektor Publik, Andi offset, Yogyakarta.

Mulyadi (2001), Balanced Scorecard Alat Manajemen Kontemporer untuk Pelipatganda Kinerja Keuangan Perusahaan, Salemba Empat, Jakarta.

Wisnubroto, Petrus dan Irawati, Nenny (2008), Analisis Pengukuran Kinerja dengan Metode Balanced Scorecard, Jurnal Teknologi, Volume 1, No.2, Hal 178-190.

Rohm, Howard (2004), Improve Public Sector results With A Balanced Scorecard: Nine Steps To Succcess, http: Ilwww.balancedscorecard.org.

Siagian, Sondang. P (1995), Manajemen Strategik, Bumi Aksara, Jakarta.

Wilopo (2003), Improvisasi Manajemen Strategis Sektor Publik, Jurnal Administrasi Negara, Volume 3, No.1. 
